\title{
TANTANGAN INTERKONEKSI SAINS DAN AGAMA DI IAIN SUNAN AMPEL
}

\author{
Muhammad Fahmi \\ (Dosen STAI Taruna Surabaya; Honorer IAIN Sunan Ampel)
}

\begin{abstract}
Abstrak
Tulisan ini berusaha mengeksplorasi konsep interkoneksi keilmuan agama dan umum melalui integrated twin towers di IAIN Sunan Ampel beserta tantangan yag melingkupinya. Pengembangan epistemologi integrated twin towers yang berupaya menginterkoneksikan keilmuan agama dan umum dengan grand design yang sedang digodok oleh para petinggi IAIN Sunan Ampel baru sebatas asumsi, dan tetap rentan mengandung resiko dan penuh tantangan. Asumsinya adalah keilmuan agama dan umum yang integratif-interkonektif, dan resikonya adalah keilmuan agama dan umum yang semakin dikotomis dengan simbol menara kembar. Sementara itu tantangannya adalah ego SDM ilmu agama dan umum. Meskipun penuh resiko dan tantangan, namun upaya integrasi-interkoneksi keilmuan agama dan umum melalui epistemologi integrated twin towers perlu terus dilakukan.

Asumsi keilmuan yang integratif-interkonektif melalui epistemologi integrated twin towers harus dikawal dengan perangkat sistem yang mendukung realisasinya. Apabila tidak melalui pengawalan sistem, yang terjadi bisa sebaliknya, bukan keilmuan yang integratif tetapi keilmuan yang semakin dikotomis antara agama dan umum, karena ada pelambangan berupa simbol menara kembar keilmuan, dimana keilmuan agama ada pada menara tersendiri dan keilmuan umum ada pada menara tersendiri. Bentuk pengawalan sistem yang ada bisa berupa seleksi penerimaan tenaga dosen atau karyawan yang mana dalam perekrutan harus dipastikan calon tenaga dosen atau karyawan adalah orang-orang yang mempunyai pemahaman keagamaan dan umum serta bidang yang akan digelutinya secara cukup. Jadi materi soal yang dijadikan acuan tes harus juga bersifat integratif.
\end{abstract}

Kata Kunci: Dikotomi, Interkoneksi dan Integrated Twin Towers 


\section{A. Pendahuluan}

Dunia Islam -pada kisaran abad ke VI - XII M- mengalami supremasi kejayaan dan kemegahan dalam hal ilmu pengetahuan, teknologi, dan peradaban. Hal itu ditandai dengan maraknya kajian tentang ilmu pengetahuan dan filsafat, sehingga saat itu dunia Islam menjadi mercusuar dunia, baik di belahan Timur maupun Barat. Masa tersebut telah mampu melahirkan banyak saintis dan filosof kaliber dunia di berbagai lapangan ilmu pengetahuan. Dalam bidang fikih telah ada Imam Malik, Imam Syafi'i, Imam Abu Hanifah, Imam Ahmad bin Hanbal. Dalam bidang filsafat ada al-Kindi, al-Farabi, Ibnu Sina, dan Abu Yazid. Dalam bidang sains terdapat Ibnu Hayyam, al-Khawarizmi, al-Razi, dan al-Mas'udi. ${ }^{1}$

Kondisi sebagaimana di atas dapat terealisasi karena ilmu pengetahuan, filsafat, dan agama diyakini sebagai suatu totalitas dan integralitas ajaran Islam yang tidak dipisahkan secara dikotomis antara satu dengan yang lain. Ada interkoneksi antara sains dan agama secara baik. Posisi ilmu pengetahuan dan siapapun yang mencarinya, secara religius dipandang tinggi dan luhur. Mereka melakukan eksplorasi ilmu pengetahuan dan filsafat dengan tidak bertendensi pada persoalan materi semata, tetapi karena semangat religiusitas dan terdorong oleh sebuah keyakinan bahwa aktivitas tersebut merupakan bagian terpadu dari perwujudan ajaran agama (perintah Allah SWT). ${ }^{2}$

Kondisi gemilang di bidang keilmuan yang telah dicapai oleh dunia Islam, pada sekitar pertengahan abad ke-12 M. mulai bergeser dan sedikit demi sedikit menjauh dari dunia Islam. Hal tersebut berawal dari terjadinya disintegrasi pemerintahan Islam yang berimplikasi pada munculnya sekte-sekte politik yang sparatif-kontradiktif. Sebagian kelompok, secara politis memproklamirkan diri pada ketertutupan pintu ijtihad dan menggiring umat Islam ke sudut pemaknaan agama yang eksklusif serta mengisolasikan ilmu pengetahuan dan filsafat dari dimensi agama. Hal ini berefek pada terjadinya stagnasi sains di dunia Islam, serta berakibat pada kerapuhan umat Islam dalam berbagai aspek kehidupan;

\footnotetext{
${ }^{1}$ Harun Nasution, Pembaharuan dalam Islam (Jakarta: Bulan Bintang, 1975), 13.

${ }^{2}$ Muhammad Qutb, Qabasat min al-Rasul (Makkah: Dar al-Syarqi, 1982), 42-43. 
baik ekonomi, politik, militer, maupun aspek ilmu pengetahuan dan teknologi. ${ }^{3}$

Keadaan yang kritis sebagaimana tersebut di atas dimanfaatkan oleh dunia Barat sebagai kesempatan untuk menjejaskan kaki kolonialisme dan imperialisme terhadap dunia Islam. Wilayah-wilayah Islam satu persatu ditaklukkan dengan mudah. Pada akhirnya suramlah dunia Islam dan reduplah pamornya di mata dunia sampai sekarang. Mengomentari hal itu, Isma'il Raji al-Faruqi menyatakan bahwa umat Islam di dunia ini merupakan umat yang kondisinya paling tidak menggembirakan, sekalipun dalam kuantitas besar dan berdomisili di dataran bumi yang subur dan kaya sumber daya alamnya. ${ }^{4}$

Memasuki abad ke-18 M, umat Islam mulai terbangun dari tidur panjangnya. Jatuhnya Mesir ke tangan bangsa Barat menyadarkan dan membuka mata umat Islam bahwa di Barat telah muncul peradaban baru yang lebih tinggi dan sekaligus menjadi ancaman besar bagi umat Islam. ${ }^{5}$ Mulai saat itu muncul di kalangan intelektual Islam ide-ide untuk mempelajari ilmu pengetahuan Barat yang sekularistik dan rasionalmaterialistik serta terpisah sama sekali dari semangat dan nilai-nilai moralitas Islam.

Persentuhan dunia Islam dengan ilmu pengetahuan Barat itu akhirnya menimbulkan persaingan dan dua macam respon yang saling bersimpangan jalan di kalangan intelektual Muslim. Satu sisi menampakkan sikap antagonistik-kontradiktif, bahkan mereka menganggap ilmu pengetahuan Barat sebagai karya-karya jahat dan hanya sebagai gembar-gembor dunia yang hampa. Di sisi lain, terdapat kelompok intelektual Muslim yang menunjukkan sikap protagoniskompromistis dan bombastis, bahkan terpaku dan terjerembab dalam metodologi sekular sains modern, misalnya: Muhammad Hisyam Haykal, Thaha Husain, dan Ali Abdul Raziq. Ketiga intelektual tersebut

\footnotetext{
${ }^{3}$ Harun Nasution, Pembaharuan dalam Islam, 13.

${ }^{4}$ Isma'il Raji al-Faruqi, Tauhid,, terj. Rahmani Astuti (Bandung: Pustaka, 1982), vii. 5 Isma'il Raji al-Faruqi, "Science and Traditional Values in Islamic Society", dalam Zygon, Journal of Religion and Science, Vol. 2, Nomor 3, 1967, 23.
} 
berpegang seutuhnya pada pandangan sains modern, bahkan mereka dengan terbuka mengekspresikan sentimen-sentimen anti agama. ${ }^{6}$

Situasi semacam tersebut di atas tentu mempertajam kesenjangan antara ilmu pengetahuan dan agama dan memperkuat dikotomi keilmuan (agama dan umum) yang pada gilirannya merambat pada dikotomi model pendidikan. Di satu pihak, ada pendidikan yang hanya memperdalam ilmu pengetahuan modern yang kering dari nilai-nilai moralitas agama (baca: Islam); sementara di pihak lain, terdapat pendidikan yang hanya mendalami ilmu agama yang terpisahkan sama sekali dari perkembangan ilmu pengetahuan kontemporer.

Kelompok yang pertama hanya berorientasi pada upaya melahirkan para saintis sekular yang sama sekali terlepas bahkan alergi terhadap prinsip-prinsip dan nilai-nilai moralitas agama; sedangkan kelompok yang kedua hanya berorientasi pada upaya melahirkan intelektual agama yang berwawasan eksklusif dan memisahkan bahkan melempar jauh-jauh ilmu pengetahuan umum dari paradigma pemahaman dan pemaknaan agama. Ahmad Watik Pratiknya menyatakan bahwa munculnya kecenderungan dikotomi sesungguhnya berangkat dari kegagalan umat Islam untuk memahami dan menangkap hubungan antara ilmu (science) dan agama secara proporsional. ${ }^{7}$

\section{B. Akar Masalah Dikotomi Keilmuan}

Dunia pendidikan Islam sebagian masih mengalami problematika dalam hal keilmuan yang dikotomis (agama dan umum) serta proses dan tujuan yang bersifat parsial. Hal itu berimplikasi pada dualisme sistem pendidikan Islam (tradisional dan modern). Dunia Islam mulai terputus hubungannya dari peran utama dalam sains dan teknologi (ilmu umum) menjelang akhir abad ke-16 M. Semenjak itu Eropa Barat dan Amerika mengayunkan langkahnya ke depan secara dinamis seiring dengan kemajuan iptek-nya, sementara Islam berpuas diri dalam keterpencilan

\footnotetext{
${ }^{6}$ Osman Bakar, Tauhid dan Sains, terj. Yuliani Liputo (Bandung: Pustaka Hidayah, 1991), 220.

7 Ahmad Watik Pratiknya, "Identifikasi Masalah Pendidikan Agama Islam di Indonesia", dalam Muslih (Ed.), Pendidikan Islam di Indonesia (Yogyakarta: Tiara Wacana, 1991), 104.

Jurnal Pendidikan Agama Islam

Volume 02 Nomor 02 November 2013

Hal $322-337$
} 
intelektual. Ketika dunia Barat mulai mengusik mereka secara tiba-tiba, dunia Islam terbangun dan mendapati dirinya dalam ketertinggalan dan ketidakberdayaan. Kemerdekaan politik dan intelektual dikuasai dunia Barat. $^{8}$

Penyebab kemunduran dan degenerasi kaum Muslimin -menurut Naquib Al-Attas menyatakan- adalah karena kelalaiannya dalam merumuskan dan mengembangkan rencana pendidikan yang sistematis berdasarkan prinsip-prinsip Islam, juga kelalaiannya dalam melaksanakan suatu sistem pendidikan yang terkoordinasikan dan terpadu. ${ }^{9}$ Hal ini antara lain- yang menyebabkan stagnasi panjang dalam hal pendidikan yang terjadi di dunia Islam, dan berakibat pada dikotomi pendidikan Islam.

Dalam pandangan Isma'il Raji Al-Faruqi, problem kurikulum pendidikan Islam yang selama ini terkelompokkan secara dikotomis menjadi keilmuan Barat (sekular) dan agama, proses pendidikan yang tidak integratif, dan tujuan pendidikan Islam yang bersifat parsial adalah karena sepinya nilai-nilai Islam yang utuh dalam berbagai aspek kependidikan Islam. ${ }^{10}$ Oleh karena itu kurikulum keilmuan, proses dan tujuan pendidikan Islam harus diwarnai dengan nilai-nilai Islam secara utuh.

Al-Faruqi menyatakan bahwa ilmu pengetahuan modern harus dibingkai dengan prinsip-prinsip Tauhid kepada Allah SWT. Allah SWT adalah Pencipta dan Pemilik alam semesta ini, sedangkan manusia hanya diizinkan tinggal dan hidup di dalamnya untuk memenuhi tujuan-tujuan yang telah ditentukan-Nya, yaitu memperbaiki dan mengatur serta memanfaatkan sebaik-baiknya dengan cara mengaji segala rahasia yang ada dan mungkin ada di baliknya; juga tidak ada hak bagi manusia untuk membuat kerusakan di dalamnya. ${ }^{11}$

8 Ikhrom, "Dikhotomi Sistem Pendidikan Islam", dalam Ismail SM., (ed.), Paradigma Pendidikan Islam (Yogyakarta: Pustaka Pelajar, 2001), 82.

9 Syed Muhammad Naquib al-Attas, Islam and Secularism, terj. Karsidjo Djojosuwarno (Bandung: Pustaka, 1981), 178.

${ }^{10}$ Isma'il Raji al-Faruqi, Al-Tawhid: Its Implications for Thought and Life, Third Edition, (USA, Herndon, Virginia: International Institute of Islamic Thought, 1995).

${ }^{11}$ Isma'il Raji al-Faruqi, Tauhid....., 59. 
Pada abad XXI M, yang bibit-bitnya sudah dimulai pada abad XVIII M, umat Islam menapaki babak baru, karena terjadi perubahan mendasar di dunia Islam, yaitu pembaharuan. Dalam konteks Indonesia, menurut Karel A. Steenbrink, ${ }^{12}$ setidaknya ada empat faktor yang mendorong pembaharuan Islam; 1) keinginan untuk kembali kepada alQur'an dan al-Hadits, 2) semangat nasionalisme untuk melawan penjajah, 3) memperkuat basis gerakan sosial, ekonomi, budaya, dan politik, dan 4) pembaharuan pendidikan Islam di Indonesia. Modernisasi pendidikan Islam di Indonesia terinspirasi oleh model pendidikan penjajah. Modernisasi ini setidaknya dapat dilihat pada pembentukan lembagalembaga pendidikan modern yang mengadopsi sistem pendidikan Barat.

\section{Ragam Terobosan Interkoneksi Keilmuan}

Dalam rangka upaya pengembalian totalitas dan integralitas pemahaman dan pemaknaan Islam akan ilmu pengetahuan, beberapa intelektual Muslim -antara lain- telah berusaha mencari solusi yang signifikan dan akurat dengan merekonstruksi paradigma pemikiran Islam yang populer disebut dengan "Islamisasi Ilmu Pengetahuan", yaitu menerima secara positif sains modern dalam bingkai prinsip-prinsip dan nilai-nilai Islam. ${ }^{13}$ Di antara intelektual Muslim yang menginisiasi ide-ide Islamisasi ilmu pengetahuan adalah Isma'il Raji al-Faruqi dan Naquib AlAttas. Mereka memiliki persepsi bahwa ilmu pengetahuan modern telah bersifat sekular dan karenanya ia jauh dari kerangka Tauhid. Oleh karena itu, mereka menyerukan adanya renovasi dan rekonstruksi sistem pendidikan Islam yang mengarah pada kerangka Islamisasi ilmu pengetahuan. ${ }^{14}$

Islamisasi ilmu pengetahuan (Islamization of knowledge) merupakan bagian dari upaya intelektual Muslim untuk melakukan integrasi dan interkoneksi keilmuan dan memecahkan problem dikotomi

\footnotetext{
12 Karel A. Steenbrink, Pesantren, Madrasah, Sekolah: Pendidikan Islam dalam Kurun Modern (Jakarta: LP3ES, 1994), 26.

${ }^{13}$ Osman Bakar, Tauhid dan Sains, 233.

${ }^{14}$ John L. Esposito, "Isma'il Raji al-Faruqi", dalam John L. Esposito (Ed.), The Oxfort Encyclopedia of The Modern Islamic World, Vol. 2 (New York: Oxford University Press, 1995), 3.

Jurnal Pendidikan Agama Islam

Volume 02 Nomor 02 November 2013

Hal $324-337$
} 
keilmuan dalam pendidikan Islam. ${ }^{15}$ Meski demikian, dalam merespon proyek Islamisasi ilmu pengetahuan tersebut, ada yang pro dan ada yang kontra di kalangan intelektual Muslim sendiri, termasuk di Indonesia. ${ }^{16}$ Di satu pihak, ada yang bersikap protagonis dan positif terhadap Islamisasi ilmu pengetahuan dengan beragam argumen yang dikemukakan. Di pihak lain, ada yang bersikap antagonis dan negatif terhadap proyek Islamisasi ilmu pengetahuan dengan beragam argumen yang ada.

Beberapa intelektual Muslim dewasa ini yang termasuk dalam kelompok yang kurang sepaham dengan konsep integrasi keilmuan berbasis Islamisasi ilmu adalah intelektual IAIN Sunan Ampel. Beberapa intelektual IAIN Sunan Ampel lebih setuju dengan upaya interkoneksi keilmuan berbasis integrated twin towers (menara kembar tersambung), dimana untuk membaurkan keilmuan agama dan umum, tidak perlu upaya Islamisasi ilmu. Biarkan keilmuan agama dan umum berjalan sesuai dengan rel masing-masing, yang penting, pada puncak kedua keilmuan itu harus disambungkan dan dikomunikasikan.

Kerangka epistemologi integrated twin towers yang menjadi konsep andalan IAIN Sunan Ampel saat ini, yang lazim disebut dengan paradigma keilmuan integratif-interkonektif, dengan simbol dua bangunan besar menjulang tinggi keatas, merupakan sebuah gagasan konseptual yang mengidealisasikan hubungan terpadu antara ilmu-ilmu keislaman dengan ilmu-ilmu umum. ${ }^{17}$ Paradigma ini lahir dari sebuah keprihatinan terhadap kesenjangan keilmuan di IAIN selama ini yang bersifat dikotomis antara ilmu agama dan ilmu umum. Kedua wilayah ilmu pengetahuan itu tidak "saling menyapa" satu sama lain; bahkan ilmu

\footnotetext{
${ }^{15}$ Isma'il Raji al-Faruqi, Islamisasi Ilmu Pengetahuan, terj. A. Mahyudin (Bandung: Pustaka, 1984). Al-Faruqi sangat terobsesi untuk mengislamisasikan ilmu pengetahuan; Azyumardi Azra, "Dari Arabisme ke Khilafatisme: Kasus Isma'il alFaruqi”, dalam Azyumardi Azra, Pergolakan Politik Islam (Jakarta: Paramadina, 1996).

16 Ahmad Baidowi, "Islamisasi Ilmu Pengetahuan: Sebuah Respon terhadap Gagasan Isma'il Raji al-Faruqi", dalam Refleksi (Yogyakarta: IAIN SuKa Ushuludin, 2002).

${ }^{17}$ IAIN News, IAIN ke UIN Selangkah Lagi, Edisi Kwartal Kedua Novermber 2010, Artikel, Ikon itu Bernama Integrated Twin Tower, 8.
} 
umum cenderung dipandang "barang asing" yang tidak memiliki relevansi dengan disiplin ilmu keagamaan di PTAI.

Pemikiran tentang integrasi dan interkoneksi antara ilmu pengetahuan agama dan umum bukan merupakan fenomena baru dalam khazanah epistemologi keilmuan Islam. Karena ajaran Islam memang tidak mendikotomikan antara ilmu agama dan ilmu umum. Apabila ditelususri lebih jauh, gagasan tentang integrasi-interkoneksi antara ilmu agama dengan ilmu umum ini sebenarnya tidak lepas dari rangkaian panjang pergulatan aktualiasasi diri umat Islam terhadap proses modernisasi dunia yang tengah berlangsung dalam skala globalisasi.

Konsep ajaran Islam dan tantangan modernitas merupakan tema paling menonjol dalam agenda pembaharuan pemikiran Islam yang didengungkan oleh para mujaddid Islam sepanjang sejarah. Kekuatan tema ini terutama berkaitan erat dengan realitas kemunduran dan keterbelakangan umat Islam dalam berbagai aspek kehidupan vis a vis kemajuan dunia Barat. Salah satu fokus garapan para pembaharu dalam proses modernisasi Islam adalah bidang pendidikan.

Urusan pendidikan di dunia Islam dipandang sebagai sektor terbelakang yang menghambat laju percepatan modernisasi di dunia Islam, akibat pola pikir umat yang terkondisikan oleh anggapan bahwa antara agama yang bersumber dari wahyu dan sains yang bersumber dari hasil pikiran manusia merupakan dua entitas berbeda yang tidak berkaitkelindan satu sama lain. Akibat pemahaman terbelah ini, konsep pendidikan Islam yang semula tidak memisahkan antara kebutuhan terhadap agama dan ilmu, iman dan amal, serta dunia dan akhirat, kemudian mengalami kejumudan yang berdampak pada penjajahan supremasi Barat atas dunia Islam.

Dalam persepsi para pembaharu Islam, reformasi dunia Islam harus dimulai dari ranah pendidikan, baik sistem dan orientasi metodologi maupun format kelembagaan. Di Indonesia, realitas historissosiologis ini pula yang mengilhami tuntutan pelaksanaan konversi IAIN menjadi UIN dengan orientasi keilmuan yang integratif-interkonektif antara ilmu agama dengan ilmu umum. ${ }^{18}$ Dalam konteks UIN Sunan Ampel, orientasi keilmuan yang integratif-interkonektif tersebut

${ }^{18}$ IAIN News, IAIN ke UIN Selangkah Lagi, 9.

Jurnal Pendidikan Agama Islam

Volume 02 Nomor 02 November 2013

Hal $326-337$ 
diistilahkan dengan epistemologi integrated twin towers. Di UIN Malik Ibrahim, integrasi keilmuan dilakukan dengan basis pohon ilmu. Di UIN Sunan Kalijaga, interkoneksi ilmu dilakukan dengan kerangka jarring laba-laba. Di UIN Syarif Hidayatullah, pemaduan ilmu dilakukan dengan paradigm integrasi-interkoneksi.

Pemahaman integrasi-interkoneksi ilmu agama dan ilmu umum pada dataran objek forma di atas, ilmu-ilmu keislaman yang mengandung nilai normatif-formalistik-doktrinal dapat disenyawakan dengan ilmu umum yang berkecenderungan sosiologis-historis-empiris untuk menghasilkan suatu bangunan keilmuan baru. Melalui gabungan kedua perspektif ilmu ini, baik ilmu agama maupun ilmu umum, diasumsikan tidak saling mensubordinasi tetapi berada dalam suatu kesatuan yang seimbang. ${ }^{19}$ Dengan demikian, paradigma integratif-interkonektif yang dimaksud adalah sebuah hubungan keilmuan yang terpadu antara ilmu agama dan umum pada dataran objek formal dimana antara kedua ilmu yang berbeda ditempatkan pada posisi tidak saling mensubordinasi. ${ }^{20}$

Paradigma keilmuan integrated twin towers bukanlah proses Islamisasi ilmu. Desain integrated twin towers berbeda dengan Islamisasi ilmu. Dalam paradigma integrated twin towers, tidak ada upaya untuk mengislamisasikan ilmu pengetahuan. Meskipun keduanya (antara integrated twin towers dan Islamisasi ilmu) merupakan gagasan yang berupaya untuk mengintegrasikan keilmuan agama dan umum dalam dunia pendidikan Islam, namun keduanya memiliki desain yang berbeda.

\section{Mengkaji Interkoneksi Keilmuan di IAIN Sunan Ampel}

Para pembaharu pendidikan Islam sudah berupaya untuk mengintegrasikan keilmuan agama dan umum dalam pendidikan Islam. Al-Faruqi dan Al-Attas, misalnya, mengemukakan gagasan Islamisasi ilmu dalam rangka mengintegrasikan keilmuan agama dan umum; klasik dan modern; Islam dan Barat, dalam dunia pendidikan Islam. Sementara IAIN Sunan Ampel saat ini telah berupaya mendesain konsep integrasi

\footnotetext{
${ }^{19}$ Nur Syam, Membangun Keilmuan Islam Multidisipliner.

${ }^{20}$ Supriatna \& Ahmad Pattiroy, Paradigma Integratif-Interkonekif, (Yogyakarta: UIN Kalijaga, 2005).
} 
keilmuan agama dan umum dengan basis epistemologi integrated twin towers.

Menurut Nur Syam, ada beragam dasar dan pembidangan ilmu pengetahuan yang dapat dijadikan sebagai patokan untuk menentukan bidang ilmu, disiplin dan sub disiplinnya. ${ }^{21}$ Pertama, dari aspek fungsi ilmu, apakah ilmu teoretis atau praktis, ilmu murni atau terapan. Pembagian ilmu berdasarkan fungsi itu mengandung kelemahan dan menyulitkan karena basis fungsi tersebut terkadang bercorak dualisitik, artinya di satu sisi mengandung ilmu-ilmu teoretik, di sisi lain memiliki basis praktis; dalam hal ini bisa terjadi tumpang tindih.

Kedua, pembidangan ilmu berdasarkan sasaran kajian (objek studi, subject matter). Melalui sasaran kajian, maka akan terdapat kejelasan tentang suatu ilmu akan masuk dalam bidang apa. Sehingga, setiap ilmu yang memiliki objek materia yang sama dapat dikelompokkan dalam satu bidang yang sama. Perbedaan antara satu ilmu dengan lainnya sering dilihat dari objek forma ilmu yang bersangkutan. Ilmu-ilmu alam, misalnya, memiliki objek materi yang berupa gejala-gejala alam yang ajeg dan bercorak nomotetis, ilmu-ilmu sosial memiliki objek materi gejala kemasyarakatan dan ideografis, sedang ilmu budaya dan humaniora memiliki objek materi gejala-gejala kemanusiaan. Dari objek kajian tersebut, muncullah berbagai disiplin karena adanya objek forma yang berbeda.

Ketiga, melalui pendekatan, yaitu upaya untuk memadukan berbagai disiplin keilmuan dengan memosisikan satu disiplin sebagai pendekatan dan yang lain sebagai sasaran kajian. Melalui pendekatan, maka ilmu pengetahuan akan berkembang dengan cepat karena dimungkinkan tumbuhnya disiplin-disiplin baru yang merupakan gabungan antara dua ilmu pengetahuan. Inilah yang disebut sebagai interdisciplinarity (antar bidang) dan cross-disciplinarity (lintas bidang) atau yang secara umum disebut sebagai multi-disciplinarity (multidisiplin).

Pada perkembangan keillmuan berikutnya, muncul disiplin sosiologi agama (perpaduan antara sosiologi dalam bidang social science dan agama dalam bidang culture and humanity) yang selanjutnya disebut sebagai cross-disciplinarity. Demikian pula antropologi agama, psikologi

\footnotetext{
${ }^{21}$ IAIN News, IAIN ke UIN Selangkah Lagi, 9.
} 
agama, filsafat sosial, filsafat hukum, sejarah sosial, dan sebagainya. Di sisi lain, sosiologi politik, misalnya, merupakan jenis keilmuan interdiscipliner karena merupakan penggabungan sosiologi sebagai bagian dari bidang social science dan politik yang juga bagian dari social science. Demikian pula, sosiologi hukum, antropologi politik, psikologi sosial, dan sebagainya. ${ }^{22}$

Berdasarkan pandangan kaum positivis agama disejajarkan dengan mitos dan diramalkan akan tenggelam ditelan oleh zaman yang semakin modern dan positif, tetapi ternyata dewasa ini agama sedang menuai zamannya. Maka hipotesis kaum positivis tersebut tidak menuai kenyataan. Sekarang ini bukan hanya kerinduan masyarakat untuk menjadi semakin beragama, yang dikenal sebagai kebangkitan agamaagama, akan tetapi juga minat akademisi untuk mengkaji agama dalam kaitannya dengan disiplin ilmu lain juga sedang menggejala. Sebagai contoh tentang bagaimana memadukan antara disiplin ilmu-ilmu sosial dan culture/ humanities dengan agama sebagai sasaran kajian, di antaranya mengkaji agama berdasarkan pendekatan antropologis, feminis, fenomenologis, filosofis, sosiologis dan teologis.

Pembidangan ilmu-ilmu keislaman juga diusahakan melalui pengategorian apa yang menjadi sasaran kajiannya. Oleh karena itu, ditemukanlah pembidangan seperti Ilmu Al-Quran yang kajiannya adalah Al-Quran. Ilmu Hadits yang menempatkan kajiannya pada Hadits-hadits Nabi. Ilmu Akidah yang memiliki kajian berupa dimensi-dimensi keyakinan terhadap Tuhan dan hal-hal yang terkait dengannya. Ilmu Dakwah memiliki kajian yang terkait dengan penyebaran ajaran Islam. Ilmu Tarbiyah memiliki kajian berupa pendidikan Islam. Ilmu Syariah memiliki kajian berupa hukum Islam dan implikasinya.

Berpijak pada realitas pergerakan relasi agama dan sains ini, sungguh menarik untuk diperbincangkan bagaimana membangun relasi antara sains (ilmu kealaman dan ilmu sosial) dengan agama. Di antara jawaban itu adalah melalui pendekatan (approach) yang mempertemukan suatu disiplin ilmu dengan agama; dan sebagaimana telah diungkapkan di

${ }^{22}$ IAIN News, IAIN ke UIN Selangkah Lagi, 9. 
atas bahwa suatu disiplin ilmu akan menjadi pendekatan dan lainnya menjadi objek kajian (subject matter). ${ }^{23}$

Konsep menara kembar tersambung (integrated twin towers) di dalam pengembangan ilmu keislaman multidisipliner di IAIN Sunan Ampel yang dimaksudkan adalah membangun struktur keilmuan yang mana antara ilmu keagamaan dan ilmu sosial/humaniora serta ilmu alam berkembang secara memadai dan wajar. Kesemuanya memiliki kewibawaan yang sama, sehingga antara satu dengan lainnya tidak saling merasa superior atau inferior. Ilmu keislaman berkembang dalam kapasitas dan kemungkinan perkembangannya, demikian pula ilmu lainnya juga berkembang dalam rentangan dan kapasitasnya. Ilmu keislaman laksana sebuah menara yang satu dan ilmu lainnya seperti menara yang satunya lagi. Keduanya bertemu dalam puncak yang saling menyapa, yang dikenal dengan konsep ilmu keislaman multidisipliner.

Dalam desain epistemologi integrated twin towers ditegaskan bahwa fondasi keilmuannya ialah Al-Quran dan Al-Hadits, kemudian menaranya terdiri dari ilmu keislaman murni dan terapan (tafsir, hadits, Ilmu Fiqh, Ilmu Kalam, Tasawuf, ilmu dakwah, ilmu tarbiyah dan sebagainya), kemudian menara lainnya adalah ilmu alam, ilmu sosial dan humaniora (ilmu kimia, fisika, sosiologi, antropologi, politik, psikhologi, sejarah, filsafat dan sebagainya), dan kemudian dipuncaknya terdapat garis yang menghubungkan antara menara satu dengan lainnya, yaitu pertautan antara dua disiplin keilmuan, sehingga terdapat sosiologi agama, filsafat agama, antropologi agama, ekonomi Islam, politik Islam, dan seterusnya.

Struktur bangunan keilmuan harus diletakkan di atas fondasi AlQuran dan Al-Hadits, sebab yang akan dibangun pada akhirnya adalah ilmu sosial profetik, ilmu alam profetik, serta culture dan humaniora profetik. Mengikuti pandangan kaum ilmuwan yang mengembangkan ilmu-ilmu yang trans-teoretik, yaitu teori yang tidak hanya digunakan untuk teori, tetapi teori untuk kemungkinan pengembangan masyarakat. Dengan demikian, setiap teori yang dihasilkan oleh ilmuwan Islam

23 Eeriksa Noeng Muhajir, Metodologi Penelitian Kualitatif (Jogyakarta: Rake Sarasin, 1991).

Jurnal Pendidikan Agama Islam

Volume 02 Nomor 02 November 2013

Hal $330-337$ 
hakikatnya adalah bertujuan untuk meningkatkan kehidupan masyarakat setahap lebih baik.

Dalam rangka mengembangkan keilmuan yang integratif dalam coraknya yang integrated twin towers tersebut maka IAIN Sunan Ampel melakukan restrukturisasi kelembagaan pada level fakultas. Sesungguhnya bukan perubahan struktur yang mendasar, tetapi terkait dengan nomenklatur fakultas yang selama ini dikenal, yaitu Fakultas Adab, Fakultas Dakwah, Fakultas Syariah, Fakultas Tarbiyah dan Fakultas Ushuluddin. Hal yang harus dipertimbangkan adalah memberikan wadah bagi pengembangan ilmu-ilmu sosial dan humaniora dalam wadah yang jelas, yaitu Fakultas Adab dan Humaniora, Fakultas Dakwah dan Ilmu Sosial, Fakultas Syariah dan Hukum, Fakultas Tarbiyah dan Keguruan serta Fakultas Ushuluddin dan Filsafat.

Memang harus dilihat realitas empiris di dalam mengembangkan keilmuan dan juga wadah pengembangannya. Model integrated twin towers pun juga bukan model yang sangat sempurna. Kekuatan model ini adalah pada kemenyatuan pada puncaknya. Menara kembar yang kemudian dipersatukan melalui jembatan penyeberangan atau pendekatan sehingga menghasilkan keilmuan yang bercorak khas. Masing-masing menara memang merupakan bidang atau disiplin ilmu yang berbeda. Antara yang satu dengan lainnya berada di ruangnya sendiri-sendiri. Hal itu tentu disebabkan oleh masing-masing objek kajiannya yang berbeda. Objek ilmu alam tentu saja berbeda dengan ilmu sosial.

Dalam konteks bidang ilmu yang berdiri sendiri tentunya harus ditempatkan di dalam rumahnya sendiri-sendiri. Sehingga gambaran realitas empirisnya menjadi sangat kuat. Kemudian, di antara menara tersebut disambungkan dengan pendekatan atau bagan epistemologis yang saling mengaitkan dua bidang yang berbeda tersebut. Jembatan pendekatan akan menghasilkan bidang ilmu yang berciri khas. Inilah yang menjadi kekuatan dari integrated twin towers. Ia merupakan gabungan dari dua bidang ilmu yang memang berbeda, tetapi dipertemukan menjadi satu melalui pembuatan atau konstruksi epistemologis yang memang disengaja untuk itu.

Di antara model realitas yang belum memberikan gambaran secara menyatu adalah pada fondasi atau basis ontologis keilmuannya. Agar menjadi menyatu basis ontologisnya atau sumber keilmuannya, 
maka dua tower ini juga harus menyatu di fondasinya. Jadi, jika di bawah menyatu di dalam fondasinya, maka di atas menyatu melalui jembatan yang menghubungkan di antara dua tower dimaksud. Kemenyatuan antara bawah dan atas, antara fondasi dan puncak, antara aspek ontologis dan epistemologis, akan menghasilkan ilmu keislaman multidispliner. Ilmu inilah nantinya yang akan membedakan antara universitas Islam dengan universitas umum dalam melihat realitas empiris di masyarakat. Islamic studies multidisipliner merupakan puncak dari cita-cita mendirikan institusi pendidikan Islam yang ideal. ${ }^{24}$

Paradigma keilmuan integratif-interkonektif merupakan bangunan keilmuan universal yang tidak memisahkan secara dikotomis antara wilayah agama dan ilmu. Dalam bangunan keilmuan ini, ilmu pengetahuan agama (Islam) tidak lagi terpisah secara dikotomis dengan ilmu pengetahuan umum sebagaimana yang terjadi selama ini. Dalam format keilmuan yang terpadu, orientasi ilmu pengetahuan yang ingin ditekankan merupakan perpaduan antara ilmu-ilmu qauliyah/ hadharah an-nash (ilmu yang bekaitan dengan teks keagamaan) dengan ilmu-ilmu kauniyah ijtima'iyah/ hadharah al-'ilm (ilmu kealaman dan kemasyarakatan) dan ilmu hadaharah al-falsafah (ilmu etika kefilsafatan).

Ilmu-ilmu keislaman yang mengandung nilai normatifformalistik-doktrinal disejajarkan dengan ilmu umum yang cenderung sosiologis-historis-empiris untuk menghasilkan suatu bangunan keilmuan baru. Melalui gabungan kedua perspektif ini, baik ilmu agama atau umum, tidak saling mensubordinasi tetapi berada dalam suatu kesatuan atau kesejajaran yang seimbang.

Pada era Islam modern pasca kolonial, gagasan ilmu pengetahuan yang integratif bergaung kembali dalam berbagai konsep, antara lain: Islamisasi ilmu pengetahuan (science), saintifikasi Al-Quran, objektifikasi ajaran Islam, pohon ilmu, jaring laba-laba ilmu, integrated twin towers, dan sebagainya. Keseluruhan konsep (grand thema) ini sebenarnya menghendaki atau mengidealkan ilmu pengetahuan Islam tidak sekedar menjadi media dakwah (ceramah), tapi dikembalikan kepada otentisitasnya sebagai sistem ilmu pengetahuan yang memiliki

\footnotetext{
${ }^{24}$ Nur Syam, Menegaskan lagi Integrative Twin Tower.
} 
fungsi transfomatif dan responsif terhadap isu-isu modern sejalan dengan tuntutan kebutuhan aktual masyarakat. ${ }^{25}$

Pertemua ilmu berlangsung pada dataran objek formal dan objek material. Pada dataran objek formal, unsur perpaduannya terkait dengan perihal metodologi (perspektif, landasan teori dan metode); sementara pada dataran objek material, unsur perpaduannya menyangkut objek kajian (materi atau sasaran pembahasan). Integrasi antara kedua objek ini dalam ilmu pengetahuan harus dilakukan secara seimbang. Apabila aspek material lebih dominan, ada kemungkinan permasalahan keislaman hanya akan menjadi objek yang dikaji dengan ilmu umum, sebagaimana terjadi di perguruan tinggi umum; sebaliknya jika aspek formal lebih dominan, kemungkinan yang terjadi adalah pembahasan fenomena sosial-budaya dari perspektif ilmu-ilmu keislaman sebagaimana terjadi dalam perguruan tinggi agama Islam.

\section{E. Tantangan Interkoneksi Keilmuan di IAIN Sunan Ampel}

Gagasan untuk melakukan integrasi-interkoneksi keilmuan agama dan umum tentu menjadi peluang yang harus direalisasikan. Meskipun demikian, ada tantangan yang akan dialami oleh para pejuang integrasi dan iterkoneksi keilmuan. Termasuk para pejuang twin towers itegrated di IAIN Sunan Ampel. Paradigma keilmuan integratif-interkonektif dalam bentuk epistemologi twin tower, itu baru sebatas asumsi; belum melihat resiko keilmuan yang semakin dikotomis yang rentan terjadi. Ketika dua keilmuan disimbolkan dengan dua bangunan yang saling terpisah lalu pada satu titik dipertemukan, bukan berarti secara otomatis akan terbangun keilmuan yang integratif. Akan tetapi bisa sebaliknya, simbol bangunan twin tower yang melambangkan keilmuan agama dan umum yang diorientasikan saling berkomunikasi, bisa tidak terealisasi dan yang terjadi justru semakin memperteguh ruang dikotomi antara ilmu agama dan umum dengan simbol yang ada. Ini merupakan resiko dan tantangan yang perlu diantisipasi.

25 Tim Depag RI., Problem dan Prospek IAIN: Antologi Pendidikan Tinggi Islam (Jakarta: Direktorat Pembinaan Perguruan Tinggi Agama Islam DEPAG RI, 2000), 71. 
Apalagi melihat kecenderungan yang terjadi dewasa ini, posisi ilmu agama sering inferior di tengah pergulatannya dengan ilmu umum. Posisi inferior itu tidak hanya di dalam perbincangan akademik tetapi juga terdapat di dalam sikap dan tindakan dosen dan mahasiswa. Menjadi mahasiswa atau dosen dan bahkan juga pimpinan perguruan tinggi agama Islam (PTAI) terkadang terasa menjadi orang nomor dua; dibandingkan dengan menjadi mahasiswa, dosen dan pimpinan perguruan tinggi umum (PTU) yang terasa menjadi orang nomor satu.

Di tengah nuansa ketidakpercayaan diri itu, tentu menjadi tugas bersama untuk membangun identitas dan harga diri sebagai mahasiswa, dosen dan pimpinan PTAI dalam kancah pergaualan dengan lainnya. Kebanggaan akan identitas itulah yang dirasakan perlu untuk dikedepankan di tengah pergaulan dunia yang semakin demokratis, terbuka dan kompetitif. Untuk menjadi bangga dan memiliki harga diri tentunya harus ada sesuatu yang bisa dibanggakan dan dihargadirikan. Salah satunya adalah keahlian yang mapan tentang bidang studi yang dikaji di institusi pendidikan tinggi agama.

Kajian perlu intens dilakukan dalam rangka menghindari dikotomi yang semakin menjadi. Apalagi ego keilmuan dalam diri seseorang itu selalu mungkin ada. Orang yang ahli ilmu umum cenderung ego dengan kemampuannya di bidang ilmu umum, dan memandang sebelah mata pada keilmuan agama; begitu juga sebaliknya. Oleh karena itu konsep menara kembar keilmuan yang sedang dicanangkan di IAIN Sunan Ampel, akan beresiko memupuk rasa ego di antara ilmuwan umum dan agama.

IAIN Sunan Ampel akan menemui kesulitan dalam hal memperoleh SDM yang dalam dirinya terpatri keahlian ilmu umum dan sekaligus ahli ilmu agama. Hal ini karena, tradisi perekrutan tenaga dosen di IAIN Sunan Ampel sistemnya bersifat parsial. Calon dosen yang ikut seleksi memperebutkan posisi dosen dengan kualifikasi keilmuan umum, biasanya tidak pakai dites materi pengetahuan agama dan juga tidak pakai dites bahasa Arab. Sementara itu calon dosen yang mengikuti seleksi memperebutkan posisi dosen dengan kualifikasi keilmuan agama, akan dites dengan materi pendidikan agama, bahasa Arab, dan juga bahasa Inggris. Dari model tradisi ini saja sudah tampak perilaku diskriminasi antara calon dosen agama dan calon dosen umum. 
Dengan demikian, kalau benar-benar mau mengintegrasikan dan menginterkoneksikan keilmuan agama dan umum, dari segi perekrutan dosen dan tenaga kependidikan lainnya, harus ada kebijakan bahwa semua calon civitas akademika Sunan Ampel harus diseleksi pengetahuan agama dan umumnya. Meskipun calon dosen tersebut akan mengisi posisi keilmuan umum, dia harus dipastikan paham tentang wawasan keagamaan. Jadi materi tes nya juga berupa bahasa Arab dan pengetahuan agama -disamping bahasa Inggris dan pengetahuan bidang studi yang bersangkutan; artinya tidak cukup hanya dites dengan soal bahasa Inggris dan pengetahuan bidang studi saja.

\section{F. Kesimpulan}

Pengembangan epistemologi integrated twin towers yang berupaya mengintegrasikan keilmuan agama dan umum dengan grand desain yang sedang digodok oleh para petinggi IAIN Sunan Ampel itu baru sebatas asumsi, dan tetap rentan mengandung resiko dan penuh tantangan. Asumsinya adalah keilmuan agama dan umum yang integratifinterkonektif, dan resikonya adalah keilmuan agama dan umum yang semakin dikotomis dengan simbol menara kembar. Sementara itu tantangannya adalah ego SDM ilmu agama dan umum.

Meskipun penuh resiko, namun upaya integrasi-interkoneksi keilmuan agama dan umum melalui epistemologi twin tower dalam menyongsong perubahannya menjadi UIN Sunan Ampel perlu terus dilakukan. Asumsi keilmuan yang integratif-interkonektif melalui epistemologi twin tower harus dikawal dengan perangkat sistem yang mendukung realisasinya. Apabila tidak melalui pengawalan sistem, yang terjadi bisa sebaliknya, bukan keilmuan yang integratif tetapi keilmuan yang semakin dikotomis antara agama dan umum, karena ada pelambangan berupa simbol menara kembar keilmuan, dimana keilmuan agama ada pada menara tersendiri dan keilmuan umum ada pada menara tersendiri. Bentuk pengawalan sistem yang ada bisa berupa seleksi penerimaan tenaga dosen atau karyawan yang mana dalam perekrutan harus dipastikan calon tenaga dosen atau karyawan adalah orang-orang yang mempunyai pemahaman keagamaan dan umum serta bidang yang 
akan digelutinya secara cukup. Jadi materi soal yang dijadikan acuan tes harus juga bersifat integratif.

\section{DAFTAR PUSTAKA}

Azyumardi Azra, "Dari Arabisme ke Khilafatisme: Kasus Isma'il al-Faruqi", dalam Azyumardi Azra, Pergolakan Politik Islam (Jakarta: Paramadina, 1996).

Ahmad Baidowi, "Islamisasi Ilmu Pengetahuan: Sebuah Respon terhadap Gagasan Isma'il Raji al-Faruqi', dalam Refleksi (Yogyakarta: IAIN SuKa Ushuludin, 2002).

Ahmad Watik Pratiknya, "Identifikasi Masalah Pendidikan Agama Islam di Indonesia", dalam Muslih (Ed.), Pendidikan Islam di Indonesia (Yogyakarta: Tiara Wacana, 1991).

Eeriksa Noeng Muhajir, Metodologi Penelitian Kualitatif (Jogyakarta: Rake Sarasin, 1991).

Harun Nasution, Pembaharuan dalam Islam (Jakarta: Bulan Bintang, 1975). Isma'il Raji al-Faruqi, Tauhid,, terj. Rahmani Astuti (Bandung: Pustaka, 1982).

Isma'il Raji al-Faruqi, "Science and Traditional Values in Islamic Society", dalam Zygon, Journal of Religion and Science, Vol. 2, Nomor 3, 1967.

Isma'il Raji al-Faruqi, Islamisasi Ilmu Pengetahuan, terj. A. Mahyudin (Bandung: Pustaka, 1984).

Isma'il Raji al-Faruqi, Al-Tawhid: Its Implications for Thought and Life, Third Edition, (USA, Herndon, Virginia: International Institute of Islamic Thought, 1995).

Ikhrom, "Dikhotomi Sistem Pendidikan Islam", dalam Ismail SM., (ed.), Paradigma Pendidikan Islam (Yogyakarta: Pustaka Pelajar, 2001).

IAIN News, IAIN ke UIN Selangkah Lagi, Edisi Kwartal Kedua Novermber 2010, Artikel, Ikon itu Bernama Integrated Twin Tower.

IAIN News, IAIN ke UIN Selangkah Lagi.

John L. Esposito, "Isma'il Raji al-Faruqi", dalam John L. Esposito (Ed.), The Oxfort Encyclopedia of The Modern Islamic World, Vol. 2 (New York: Oxford University Press, 1995). 
Karel A. Steenbrink, Pesantren, Madrasah, Sekolah: Pendidikan Islam dalam Kurun Modern (Jakarta: LP3ES, 1994).

Muhammad Qutb, Qabasat min al-Rasul (Makkah: Dar al-Syarqi, 1982).

Nur Syam, Menegaskan lagi Integrative Twin Tower.

Nur Syam, Membangun Keilmuan Islam Multidisipliner.

Osman Bakar, Tauhid dan Sains, terj. Yuliani Liputo (Bandung: Pustaka Hidayah, 1991).

Syed Muhammad Naquib al-Attas, Islam and Secularism, terj. Karsidjo Djojosuwarno (Bandung: Pustaka, 1981).

Supriatna \& Ahmad Pattiroy, Paradigma Integratif-Interkonekif, (Yogyakarta: UIN Kalijaga, 2005).

Tim Depag RI., Problem dan Prospek IAIN: Antologi Pendidikan Tinggi Islam (Jakarta: Direktorat Pembinaan Perguruan Tinggi Agama Islam DEPAG RI, 2000). 